\title{
PENGARUH MODEL PEMBELAJARAN WORD SQUARE TERHADAP KEMAMPUAN BERFIKIR KREATIF PESERTA DIDIK BIDANG STUDI IPS TERPADU MATERI POKOK PENGELOMPOKAN SUMBER DAYA ALAM DI KELAS VII SMP MUHAMMADIYAH SIBABANGUN TAHUN PELAJARAN 2018-2019
}

\author{
Andes Fuady Dharma Harahap 1), Yani Sukriah Siregar,2) \\ 1,2) FKIP Universitas Muhammadiyah Tapanuli Selatan
}

\begin{abstract}
Abstrak
Rumusan masalah dalam penelitian ini adalah: “Apakah ada Pengaruh Model Pembelajaran Word Square Terhadap Kemampuan Berpikir Kreatif Peserta Didik Bidang Studi IPS Terpadu Materi Pokok Pengelompokan Sumber Daya Alam di Kelas VII SMP Muhammadiyah Sibabangun Tahun Pelajaran 2018-2019?’.Penelitian ini bertujuan untuk mengetahui data yang objektif tentang Kemampuan Berpikir Kreatif Peserta Didik melalui Model Pembelajaran Word Square pada Bidang Studi IPS Terpadu Materi Pokok Pengelompokan Sumber Daya Alam. Penelitian ini menggunakan metode kuantitatif. Dengan populasi penelitan adalah seluruh peserta didik di kelas VII SMP Muhammadiyah Sibabangun yang berjumlah 44 orang peserta didik dan yang menjadi sampel penelitian adalah 30 orang peserta didik, dan dalam pengujian hipotesis menggunakan rumus produk moment.Analisa datang dengan menggunakan rumus statistik product moment diperoleh hasil $r$ hitung $=0,490$ sedangkan nilai $r$ tabel=0,361, ini menunjukkan $r$ hitung $>r$ tabel, ini menyatakan bahwa hipotesis alternatif (Ha) diterima ini artinya ada pengaruh model pembelajaran word square terhadap kemampuan berpikir kreatif peserta didik bidang studi IPS Terpadu materi pokok pengelompokan sumber daya alam di kelas VII SMP Muhammadiyah Sibabangun Tahun Pelajaran 2018-2019.
\end{abstract}

Kata Kunci: Word Square, Berpikir Kreatif

*Correspondence Address : andes@um-tapsel.ac.id DOI : $10.31604 /$ jips.v6i2.2019.227-232

(C) 2019 Fakultas Keguruan \& Ilmu Pendidikan UM-Tapanuli Selatan 


\section{A. Pendahuluan}

Pendidikan merupakan salah satu hal yang memegang peranan penting dalam upaya meningkatkan kualitas manusia. Baik kualitas sosial, kualitas spritual, intelektual maupun kualitas professional. Hal ini dikarenakan manusia merupakan kekuatan dalam menjalankan pembangunan. Dengan demikian, mutu pendidikan dapat menentukan tingkat keberhasilan pembangunan yang diadakan. Oleh karena itu, salah satu cara yang ditempuh adalah melalui pembangunan di berbagai bidang khususnya di bidang pendidikan sebagaimana yang telah dijelaskan dalam sistem pendidikan,

Dalam rangka meningkatkan mutu pendidikan Indonesia, berbagai usaha telah dilakukan oleh pemerintah. Adapun salah satu dari upaya meningkatkan mutu pendidikan Indonesia di antaranya ialah dengan melakukan penyempurnaan kurikulum yang berlaku pada pendidikan. Dalam dunia pendidikan sekarang ini masalah lemahnya proses belajar mengajar sudah menjadi hal yang lazim terdengar. Di dalam proses pembelajaran, peserta didik kurang di dorong untuk berpikir aktif yang mengakibatkan kemampuan dalam aspek kognitif, afektif maupun psikomotorik tidak berkembang. Proses pembelajaran di sekolah hanya diarahkan agar peserta didik mampu menghafal dengan cara yang kadang kala tidak terlepas dari unsur pemaksaan karena akan diberikan sanksi jika peserta didik tidak mampu menghafal tugas yang telah diberikan guru. Peserta didik ditugaskan untuk menimbun informasi sebanyak mungkin tanpa dituntut untuk memahami setiap kalimat demi kalimat informasi yang di hafalnya untuk dapat menghubungkan informasi tersebut kedalam kehidupan sehari-hari. Akibatnya ketika peserta didik lulus dari sekolah, mereka hanya pintar secara aspek kognitif yang sewaktu-waktu informasi yang dihafal tersebut bisa saja lupa, namun mereka kurang di afektif dan psikomotorik.

Model pembelajaran Word Square adalah model pembelajaran yang menggunakan kotak-kotak berupa tekateki silang sebagai alat dalam menyampaikan materi ajar dalam proses belajar mengajar. Membuat kotak adalah media utama dalam menyampaikan materi ajar. Kotak-kotak yang telah dipersiapkan akan diisi oleh peserta didik atau mengarsir hurufhuruf yang ada yang merupakan jawaban dari pertanyaan yang dipersiapkan oleh guru. Dengan demikian ada dua hal yang diperlukan 
Andes Fuady Dharma Harahap, Yani Sukriah Siregar

Pengaruh Model Pembelajaran Word Square Terhadap Kemampuan Berfikir Kreatif ....

dalam menggunakan model pembelajaran yaitu membuat kotak, dan pertanyaan dalam rangka mengisi kotak.

Mengajar dalam praktik adalah suatu proses untuk meningkatkan keterampilan peserta didik dengan menggunakan berbagai metode yang sesuai dengan kemampuan yang diberikan dan peralatan yang digunakan. Selain itu pembelajaran praktik merupakan suatu proses pendidikan yang berfungsi membimbing peserta didik secara sistematis dan terarah untuk dapat melakukan suatu kegiatan.

Faktanya

berdasarkan pengalaman dan pantauan penulis dalam pelaksanaan yang terjadi ketika melaksanakan Praktek Kependidikan Lapangan (PKL) dan pra penelitian kesuksesan dalam proses belajar mengajar masih belum tercapai. Penggunaan sistem pembelajaran yang menggunakan strategi dan model pembelajaran turun-temurun yakni ceramah, hafalan dan tanya jawab. Oleh karena itu, perlu dilakukan perbaikan melalui pengembangan sistem pendidikan.

Setelah peneliti melaksanakan observasi proses belajar mengajar di kelas VII SMP Muhammadiyah Sibabangun terlihat bahwa sikap dan

perhatian peserta didik masih kurang selama proses pembelajaran berlangsung, seperti peserta didik kurang menunjukkan perhatian penuh selama proses pembelajaran. Dan ini menyebabkan proses pembelajaran menjadi kurang efektif. Serta, kemampuan berpikir kreatifpeserta didik di sekolah SMP Muhammadiyah Sibabangun masih jauh dari harapan.Hal tersebut terlihat dari hasil penyebaran angket yang telah dilakukan penulis. Dan dari hasil angket menunjukkan bahwa peserta didik masih kurang dalam hal berpikir kreatif sehingga terlihat bahwa masih rendahnya kemampuan berpikir kreatif peserta didik, seperti peserta didik kurang menunjukkan kemampuan mengeluarkan dan mengembangkan pendapat yang diketahuinya selama proses pembelajaran. Keadaan ini mengakibatkan hasil belajar peserta didik kurang maksimal.

Menurut Sugiyono metode penelitian kuantitatif adalah metode penelitian yang berlandaskan pada filsafat positif, digunakan untuk meneliti pada populasi atau sampel tertentu, teknik pengambilan sampel pada umumnya dilakukan secara random, pengumpulan data menggunakan instrument penelitian, analisis data 
bersifat kuantitatif/statistic dengan tujuan untuk menguji hipotesis yang telah ditetapkan.

Populasi dalam penelitian ini adalah seluruh peserta didik di kelas VII SMP Muhammadiyah Sibabangun yang terdiri dari 2 kelas yang berjumlah 44 orang peserta didik.

Menurut Sugiyono, "Sampel adalah bagian dari jumlah dan karakteristik yang dimiliki oleh populasi tersebut". Bila populasi besar dan peneliti tidak mungkin mempelajari semua yang ada pada populasi, misalnya karena keterbatasan dana, tenaga dan waktu maka peneliti dapat menggunakan sampel yang diambil dari populasi itu.

Adapun teknik dalam pengambilan sampel dalam penelitian ini adalah cluster sampling. Cluster sampling adalah teknik memilih sebuah sampel dari kelompok-kelompok unit yang kecil.Teknik ini digunakan bilamana populasi terdiri dari kelompok individu. Beberapa cluster dipilih secara acak sebagai wakil dari populasi. Sesuai dengan namanya, penarikan sampel ini didasarkan pada gugus atau cluster. Menurut Sugiyono, Cluster Sampling adalah "cara pengambilan sampel yang berdasarkan cluster-cluster tertentu". Adapun yang menjadi sampel dalam penelitian ini adalah 30 orang peserta didik dari kelas VII A dan kelas VII B. Untuk lebih jelasnya, berikut table sampel penelitian:

\section{Pembahasan dan Hasil}

Penelitian ini membahas permasalahan pokok: "Apakah ada pengaruh model pembelajaran word square terhadap kemampuan berpikir kreatif peserta didik bidang studi IPS Terpadu materi pokok pengelompokan sumber daya alam di kelas VII SMP Muhammadiyah Sibabangun Tahun Pelajaran 2018-2019?".

Setelah dilakukan pengujian hipotesis diperoleh $r$ hitung $=0,490$ sedangkan nilai $r$ tabel $=0,361$, ini menunjukkan $r$ hitung $>r$ tabel, artinya ada pengaruh model pembelajaran word square terhadap kemampuan berpikir kreatif peserta didik bidang studi IPS Terpadu materi pokok pengelompokan sumber daya alam di kelas VII SMP Muhammadiyah Sibabangun Tahun Pelajaran 2018-2019.

Berdasarkan hasil yang diperoleh bahwa penelitian menunjukkan ada pengaruh model pembelajaran word square sesuai dengan perhitungan yang dilakukan. Sehingga penulis berasumsi bahwa dengan melakukan adanya pembaharuan model pembelajaran atau berbagai model pembelajaran yang 
diterapkan bisa menunjukkan ada kemajuan kemampuan berpikir kreatif peserta didik dalam proses pembelajaran khususnya mata pelajaran IPS.

\section{Kesimpulan}

Berdasarkan hasil analisa yang dilakukan dengan pengujian hipotesis bahwa dalam pembelajaran dengan model word square terhadap kemampuan berpikir kreatif bidang studi IPS Terpadu dapat disimpulkan sebagai berikut :

1. Data yang diperoleh dengan teknik analisa data dengan menggunakan rumus korelasi product moment. Setelah dilakukan analisa data maka $r$ hitungnya adalah 0,490 dengan melihat daftar $r$ tabel dengan jumlah sampel 30 dan taraf kesalahan 5\% diketahu $r$ tabel adalah 0,361 dengan demikian dapat diketahui $r$ hitung lebih besar dari $r$ tabel yaitu 0,490>0,361 maka hipotesis alternatif diterima ( $\mathrm{Ha}$ ) diterima.

2. Pengaruh model pembelajaran word square terhadap kemampuan berpikir kretaif peserta didik pada bidang studi IPS Terpadu materi pokok pengelompokan sumber daya alam di kelas VII SMP Muhammadiyah Sibabangun Tahun Pelajaran 2018-2019 diperoleh $r$ hitung $=0,490$ dan $r$ tabel $=0,361$, karena penulis berpatokan pada ketentuan jika $r$ hitung $>r$ tabel maka Ho ditolak dan Ha diterima, karena $r$ hitung $>$ dari $r$ tabel $(0,490>0,361)$ jadi kesimpulannya ada pengaruh model pembelajaran word square tersebut karena Ho ditolak dan $\mathrm{Ha}$ diterima.

3. Dengan terkumpulnya data-data dalam penelitian ini yang diperoleh dari peserta didik di kelas VII SMP Muhammadiyah Sibabangun Tahun Pelajaran 2018-2019 melalui penyebaran angket dan setelah data terkumpul kemudian penulis mengadakan analisa denga rumus korelasi product moment. Berdasarkan perhitungan tersebut dapat disimpulkan bahwa hipotesis yang penulis ajukan dapat diterima dan benar kebenarannya dalam pengaruh model pembelajaran word square terhadap kemampuan berpikir kreatif peserta didik pada bidang studi IPS Terpadu.

\section{Daftar Pustaka}

Andre, 2007, Belajar dan Pembelajaran, Bandung : Bumi Aksara

Arikunto, Suharsimi. 2006. Dasar-dasar Evaluasi Pendidikan. Jakarta: BumiAksara. 
Arikunto, Suharsimi. 2007. Manajemen Penelitian Pendidikan. Jakarta: Rineka Cipta.

Azwar, Syarifuddin. 2006 MetodologiPendidikan. Jakarta: Kencana

Azwar, Syarifuddin. 2010 Metodologi Pendidikan. Yogyakarta: Pustaka Belajar

Bahri, DjamarahS yaiful. 2008. Rahasia Sukses Belajar. Jakarta: Rineka Cipta

Bungin, Burhan. 2011. Metodologi Penelitian Kuantitatif. Jakarta: Kencana

Dimyanti. 2009. Belajardan Pembelajaran. Jakarta: Rineka Cipta

Donald. 2006. Psikologi Belajar. Jakarta: Rineka Cipta.

Hamzah. 2014. Model Pembelajaran Inovatif. Medan: Media Persada

Hill, Way. 2005. Metodologi Penelitian. Yogyakarta: Pustaka Pelajar

Kurniasih. 2014. Model Pembelajaran Inovatif. Medan: Media Persada

Latipah, Eva. 2012. Pengantar Psikologi Pendidikan. Yogyakarta: Pedagogia

Majid. 2014. Jurnal Pendidikan. Makassar: UIN Alahuddin Makassar

Mulyani. 2009. Proses Belajar Mengajar. Jakarta: Rineka Cipta

Nazir, Muhammad. 2005 Metode Penelitian. Jakarta: Rineka Cipta

Purwanto, Ngalim. 2010. Psikologi Pendidikan. Bandung: PT. Remaja Rosdakarya
Sudarwan, Danim.2009. Metod ePenelitian Suatu Pendekatan Praktek. Jakarta: Rineka Cipta

Sudjana. 2008. Metodologi Penelitian. Jakarta: BumiAksara

Sugiyono. 2007. Metode Penelitian Administrasi. Bandung: Alfabeta

Sukardi. 2012. Metodologi Penelitian Pendidikan. Jakarta: PT. BumiAksara

Susanto.2013. Jurnal Profit Volume. Yogyakarta: Universitas Sriwijaya 